\title{
Behavior exceeds physical forcing in the diel horizontal migration of the midwater sound-scattering layer in Hawaiian waters
}

\author{
Margaret A. McManus ${ }^{1, *}$, Kelly J. Benoit-Bird ${ }^{2}$, C. Brock Woodson ${ }^{1}$ \\ ${ }^{1}$ University of Hawaii at Manoa, Department of Oceanography, 1000 Pope Road, Honolulu, Hawaii 96822, USA \\ ${ }^{2}$ College of Oceanic and Atmospheric Sciences, Oregon State University, 104 Ocean Admin Bldg, Corvallis, Oregon 97331, USA
}

\begin{abstract}
The mesopelagic sound-scattering layer around the Hawaiian Islands undergoes diel vertical migrations. This migration also includes a significant diel horizontal onshore-offshore component. Before this study, the mechanisms underlying the horizontal movement of the mesopelagic layer had not been investigated. We took an interdisciplinary approach to evaluate relationships between the mesopelagic layer and physical oceanographic processes in the water column. The study area extended west of the leeward coast of Oahu, Hawaii. We found that the nightly inshore movement of micronekton occurs very predictably each day; onshore migration brings animals nearshore between 20:00 and 20:13 $\mathrm{h}$ and offshore migration commences between 03:30 and 03:45 h during the months of April and May. Simultaneous observations of nearshore physical flow and micronekton distribution indicate that the observed nightly inshore movement of micronekton in the sound-scattering layer is not directly due to physical processes in the nearshore environment. Rather, this nightly inshore movement of micronekton can be attributed primarily to micronekton swimming behavior. This behavior may be cued by changes in sunlight, but that cue is strongly mediated by a factor tied to the lunar phase, potentially moonlight. Horizontal migration velocities exceeded the maximum across-slope physical flow by 5 to 6 -fold. Thus, typical across-slope flows likely represent a relatively small additional cost or benefit to onshore-offshore swimming, depending on flow direction. We suggest that energy acquisition via increased prey availability nearshore far exceeds the high energetic cost of onshore and offshore migrations.
\end{abstract}

KEY WORDS: Mesopelagic layer $\cdot$ Diel migration $\cdot$ Physical processes

Resale or republication not permitted without written consent of the publisher

\section{INTRODUCTION}

Many zooplankton and micronekton organisms undergo diel vertical migrations. Usually, these animals reside in deep waters during the day and ascend into shallow waters at night (Longhurst 1976). The timing and vertical extent of these migrations are affected by light levels (Clarke 1970, Blaxter 1974, Ringelberg 1995), food resources (George 1983), temperature and other environmental factors (Enright 1977). The widespread occurrence of these movements suggests that the advantages of migration can outweigh energetic expenditures, predation risks, and other costs. Hence, diel vertical migrations have been hypothesized to result from a balance between the selective pressures of energy acquisition and expenditure on one hand, and predation risk on the other (see review by Lampert 1989).

Like most deep sound-scattering layers (Roe 1974), the mesopelagic sound-scattering layer around the Hawaiian Islands undergoes diel vertical migrations (Reid et al. 1991, Reid 1994). Unlike layers that have been extensively studied elsewhere, the migration of the mesopelagic layer in Hawaii also includes a significant diel horizontal onshore-offshore component (Benoit-Bird et al. 2001, Benoit-Bird \& Au 2004, 2006). This concurrent vertical and horizontal migration results in the micronekton layer coming to within $1 \mathrm{~km}$ 
of the shoreline, reaching into waters as shallow as $23 \mathrm{~m}$ during the night, and then returning to deeper offshore waters between 9 and $11 \mathrm{~km}$ from the shoreline during the day (Benoit-Bird \& Au 2006). Some animals in this mesopelagic layer migrate horizontally at least $11 \mathrm{~km}$ roundtrip each night (Benoit-Bird \& $\mathrm{Au}$ 2006). This unusual and unexpected horizontal migratory behavior raises the question: Is the horizontal inshore movement due to active, directed swimming or passive transport by currents during observed vertical migrations?

The interaction of physical current structure and diel migration of weakly swimming zooplankton has been investigated in other areas of abrupt topography; however, the forces underlying the movement of micronekton capable of significant swimming have received little attention. Wilson \& Boehlert (2004) showed that weakly swimming micronektonic animals were able to resist horizontal displacement. However, these organisms did not make directed horizontal movements as observed in the micronekton around the main Hawaiian Islands. In other systems, diel vertical migratory patterns have been shown to lead to retention around topographic features, despite the strength of the advective field (Valle-Levinson et al. 2004, Wilson \& Boehlert 2004).

We hypothesize that the observed, nightly inshore movement of the mesopelagic sound-scattering layer around the Hawaiian Islands is not due to physical processes in the nearshore environment, but is a direct result of micronekton behavior. Previous work supports our hypothesis (Benoit-Bird et al. 2001); however, before this study this hypothesis had not been directly tested. In addition, we investigate the possible cues initiating this movement. If horizontal migration is indeed behaviorally driven, we must ask what the physical costs of this behavior are with respect to swimming and how much physical processes add to or remove from these costs.

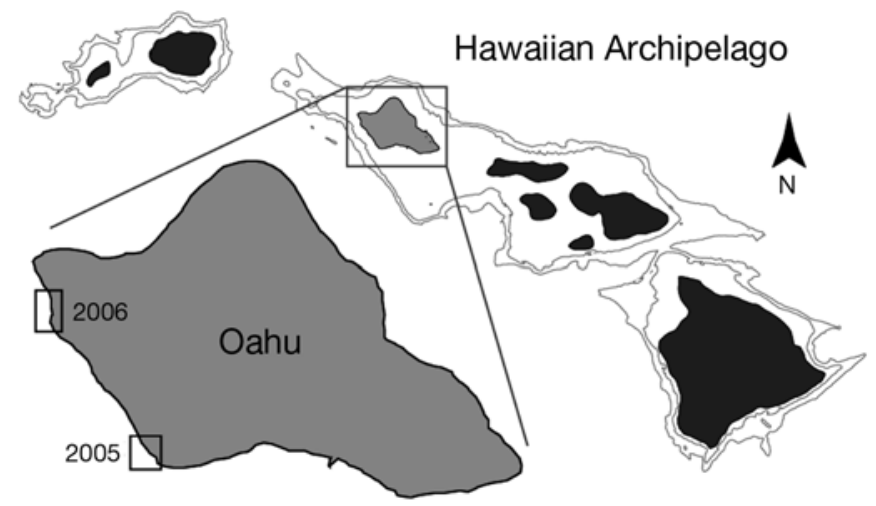

Fig. 1. Map of Hawaiian Islands showing Oahu and study areas for 2005 and 2006. $1000 \mathrm{~m}$ and $2000 \mathrm{~m}$ isobaths shown

\section{MATERIALS AND METHODS}

Study sites and sampling timeline. The study area extended west of the leeward coast of Oahu, Hawaii (Fig. 1). The study covered 2 periods, one during 2005 (April 20 to May 27) and one during 2006 (April 9 to May 16). The 2005 study site was located off the southern leeward coast of Oahu in the area of $21^{\circ} 19.3^{\prime} \mathrm{N}, 158^{\circ} 8.3^{\prime} \mathrm{W}$ (Fig. 2). The 2006 study site was located off the northern leeward coast of Oahu in the area of $21^{\circ} 30.5^{\prime} \mathrm{N}, 158^{\circ} 14.2^{\prime} \mathrm{W}$ (Fig. 3). During each period, we deployed moorings with instruments to measure physical, optical and acoustical properties of the water. We also conducted 4 shipboard surveys in 2005 and 3 shipboard surveys in 2006 during each instrument deployment. Each shipboard survey lasted for a period of $3 \mathrm{~d}$, and sampling was undertaken during night-time hours between 20:00 and 03:00 $\mathrm{h}$ local time. The shipboard surveys were designed to coincide with both spring and neap tides, spanning both ebb and flood of each tidal a

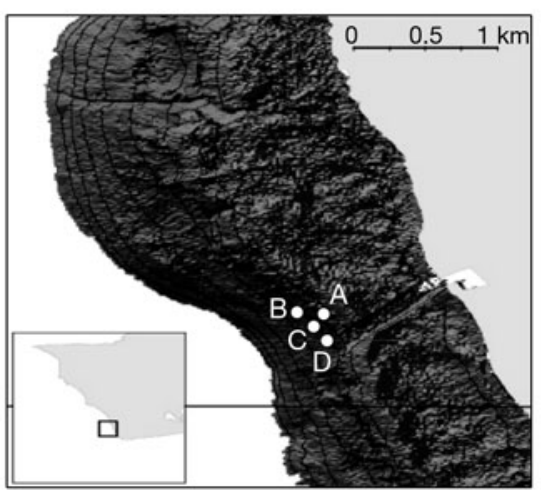

$156.10^{\circ} \mathrm{W}$ b

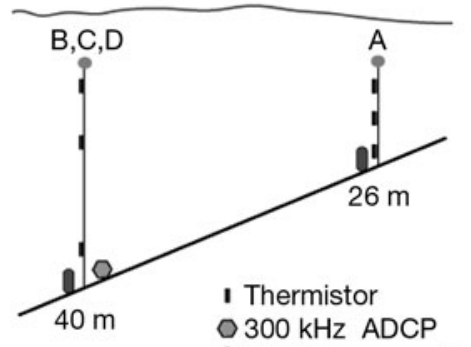

$0300 \mathrm{kHz}$ ADCP

$200 \mathrm{kHz}$ acoustic profiler

a Current meter
C

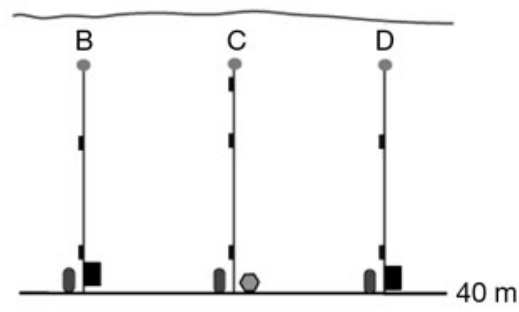

Fig. 2. Study area and instrument deployment locations for 2005 study. (a) Study area showing mooring array configuration (white dots), (b) Across-isobath view of array, showing location of moorings A (26 m) and B, C, and D (40 m), as well as instrument locations and depths, (c) Along-isobath view of array, showing location of moorings B, C and D, as well as instrument locations and depths (not to scale). ADCP: acoustic Doppler current profiler 
cycle. Data and findings from the moorings are discussed in conjunction with sea-truthing of micronekton from the shipboard surveys.

Wind and tide measurements. In 2005, hourly wind data were obtained from the Kalaeloa airfield, located $7 \mathrm{~km}$ to the east of the study site. This location is south of the Waianae mountain range with no significant terrain features between the airfield and the study site. Wind data for the region were only available for the period of 5 to 16 May 2005. Because winds can vary greatly around the Hawaiian Islands due to orographic steering, we chose not to access wind data from more distant sites. Tidal data were extracted from the pressure data recorded by the upward-looking acoustic Doppler current profiler (ADCP) at Mooring C (40 m water depth) (Fig. 2).

In 2006, hourly wind data were obtained from Waianae Harbor located $9 \mathrm{~km}$ south of the study site. Both Waianae Harbor and the study site are located in the lee of the Waianae mountain range. Tidal data were extracted from the pressure data recorded by the upward looking ADCP at Mooring B (20 m water depth) (Fig. 3).

Moorings. In 2005, we established 4 moorings on the southwestern coast of Oahu (Fig. 2, Table 1). Mooring A was located on the $26 \mathrm{~m}$ isobath, while Moorings B, C and $\mathrm{D}$, each $1 \mathrm{~km}$ apart, were located along the $40 \mathrm{~m}$ isobath. Mooring A was located $0.5 \mathrm{~km}$ northeast of Mooring C. The 2005 site has irregular bathymetry. The inner shelf widens to twice its original width as it progresses from south to north. The shelf (from the shoreline out to the $10 \mathrm{~m}$ isobath) has a gentle slope. There is a rapid change in depth between the 10 and $20 \mathrm{~m}$ isobath, then a gentle slope from 25 to $45 \mathrm{~m}$ (Fig. 2).

Instruments on each mooring in 2005 are listed in Table 1. Thermistor chains with SBE-39 thermistors (Sea-Bird Electronics) were deployed on each of the 4 moorings. The sampling interval of all thermistors was $30 \mathrm{~s}$.

At each of the 4 moorings, a custom-built, upwardlooking $200 \mathrm{kHz}$ echosounder (as in Benoit-Bird \& Au 2004) was deployed. The $200 \mathrm{kHz}$ echosounder recorded 10 echoes over $5 \mathrm{~s}$ every $15 \mathrm{~min}$ during the night and provided information on the depth and intensity of the sound-scattering layer over time.

One upward-looking $300 \mathrm{kHz}$ ADCP was deployed on Mooring C. The ADCP measured current speed and direction throughout the water column at $1 \mathrm{~m}$ vertical and 1 min temporal resolution. Data collected were good during times when the mesopelagic layer was not present in the water column.

Previous attempts to use an ADCP during the layer's migration have had limited success because of high scattering from the rapidly moving mesopelagic micronekton (Benoit-Bird et al. 2001). Consequently, in

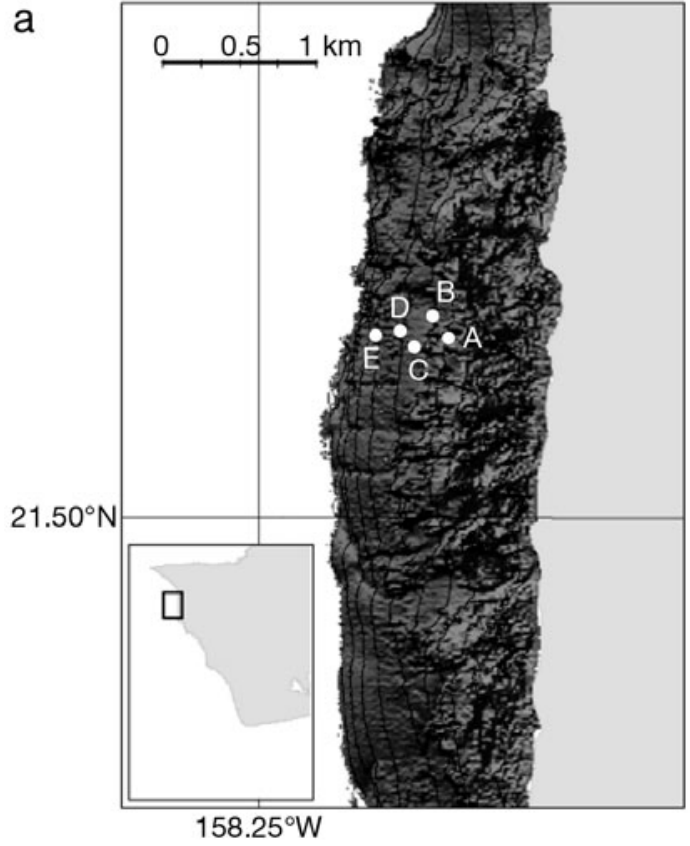

b

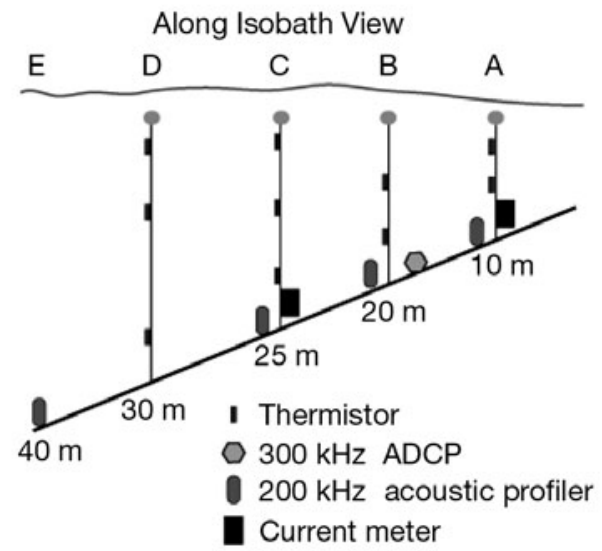

Fig. 3. Study area and instrument deployment locations for 2006. (a) Study area showing mooring array configuration (white dots), (b) Across-isobath view of array showing location of Moorings A $(10 \mathrm{~m}), \mathrm{B}(20 \mathrm{~m}), \mathrm{C}(25 \mathrm{~m}), \mathrm{D}(30 \mathrm{~m})$, and $\mathrm{E}(40 \mathrm{~m})$, as well as instrument locations and depths (not to scale)

the past, currents could only be measured when mesopelagic patches were absent. Thus, we deployed Nortek Aquadopp current meters, which produce a measurement of current magnitude and direction at a fixed point in the water column, in a near-bottom location on the thermistor chains at Moorings B and D. The sampling intervals for all Nortek current meters deployed in this study were identical. The current meters measured current speed and direction at $1 \mathrm{~min}$ resolution.

In 2006, we established 5 moorings on the northwestern coast of Oahu (Fig. 3). The 2006 site has a linear coastline, with a gentle across-shore slope from 
Table 1. Mooring locations, instrument types, and depths for 2005 and 2006 deployments

\begin{tabular}{|c|c|c|c|c|c|c|c|}
\hline Mooring site & $\begin{array}{c}\text { Water } \\
\text { depth (m) }\end{array}$ & Lat. $\left({ }^{\circ} \mathrm{N}\right)$ & Long. $\left({ }^{\circ} \mathrm{W}\right)$ & $\begin{array}{l}\text { Thermistor } \\
\text { depths (m) }\end{array}$ & $\begin{array}{c}\text { ADCP } \\
\text { measured } \\
\text { range }(\mathrm{m})\end{array}$ & $\begin{array}{c}\text { Major } \\
(y-) \text { axis } \\
\left(^{\circ}\right)\end{array}$ & Additional equipment \\
\hline \multicolumn{8}{|l|}{2005} \\
\hline A & 26 & 21.322 & 158.136 & $3,10,26$ & & & $\begin{array}{l}200 \mathrm{kHz} \text { echosounder } \\
\text { Seahorse profiler }\end{array}$ \\
\hline B & 40 & 21.327 & 158.144 & 21,39 & & & $\begin{array}{l}200 \mathrm{kHz} \text { echosounder, } \\
\text { Nortek current meter }\end{array}$ \\
\hline $\mathrm{C}$ & 40 & 21.321 & 158.137 & $4,21,39$ & $3-39$ & 158 & $200 \mathrm{kHz}$ echosounder \\
\hline $\mathrm{D}$ & 40 & 21.319 & 158.135 & 21,39 & & & $\begin{array}{l}200 \mathrm{kHz} \text { echosounder, } \\
\text { Nortek current meter }\end{array}$ \\
\hline \multicolumn{8}{|l|}{2006} \\
\hline $\mathrm{A}$ & 10 & 21.509 & 158.236 & 5,8 & - & & $\begin{array}{l}200 \mathrm{kHz} \text { echosounder } \\
\text { (ASL water column profiler), } \\
\text { Nortek current meter }\end{array}$ \\
\hline B & 20 & 21.512 & 158.238 & 10,19 & $3-19$ & 178 & $\begin{array}{l}200 \mathrm{kHz} \text { echosounder } \\
\text { Seahorse profiler }\end{array}$ \\
\hline $\mathrm{C}$ & 25 & 21.509 & 158.240 & $6,12.5,23$ & - & & $\begin{array}{l}200 \mathrm{kHz} \text { echosounder, } \\
\text { Nortek current meter }\end{array}$ \\
\hline $\mathrm{D}$ & 30 & 21.511 & 158.240 & $6,15,29$ & & & - \\
\hline E & 40 & 21.510 & 158.241 & & & & $200 \mathrm{kHz}$ echosounder \\
\hline
\end{tabular}

the $5 \mathrm{~m}$ isobath to the $45 \mathrm{~m}$ isobath. Moorings $\mathrm{A}, \mathrm{B}, \mathrm{C}$, $\mathrm{D}$, and $\mathrm{E}$ were deployed in an across-shore direction. There were horizontal distances of $0.43,0.35,0.19$ and $0.19 \mathrm{~km}$ between Moorings A and B, B and C, C and D, and $\mathrm{D}$ and $\mathrm{E}$, respectively.

Instruments moored at each site in 2006 are listed in Table 1. Thermistor chains with SBE-39 thermistors were deployed on Moorings A, B, C and D. The sampling interval of all thermistors was $30 \mathrm{~s}$. On Moorings A and C, Nortek Aquadopp current meters were deployed to measure current speed and direction in 1 min intervals near the bottom of the chains.

Upward-looking $200 \mathrm{kHz}$ echosounders (water column profiler, ASL Environmental Sciences) were deployed on Moorings A, B, C, and E. All echosounders in 2006 collected 1 echo every $4 \mathrm{~s}$ during deployment, but other signal characteristics were identical to the instruments deployed in 2005. An upward-looking $300 \mathrm{kHz}$ ADCP was deployed on Mooring B.

Shipboard surveys. The purpose of the overnight shipboard surveys was to further characterize the location of the sound-scattering layer, hydrography and optical properties in 3 dimensions. Instrumentation on the small (10 m) vessel included (1) A downward-looking acoustics package and (2) a high-resolution profiler.

The downward-looking acoustics package was attached to the side of the vessel using a custom bracket designed to fit over the vessel's gunnel. On the acoustics package were 4 downward-looking splitbeam Simrad EK 60s with frequencies of 38, 70, 120 and $200 \mathrm{kHz}$. These shipboard echosounders were used to measure the distribution of micronekton as well as to estimate their density following the methods of Benoit-Bird \& Au (2006). Direct comparisons between the $200 \mathrm{kHz}$ systems and the moored echosounders were made to confirm calibrations. In addition to the Simrad EK 60s, we used 1 downward-looking RD Instruments $600 \mathrm{kHz}$ ADCP. The ADCP measured current magnitude and direction continuously, from near surface to near-bottom in $1 \mathrm{~m}$ vertical resolution.

The high-resolution shipboard profiler was equipped with a SBE-25 CTD (temperature, salinity, pressure), an optical plankton counter (OPC) and Tracor acoustic profiling system (TAPS) for assessing zooplankton, and a low-light camera system to identify micronekton and to measure size and numerical density of animals. The high-resolution shipboard profiler is designed to be slightly negatively buoyant. This shipboard profiler descends at a rate of $\sim 5 \mathrm{~cm} \mathrm{~s}^{-1}$ and a majority of the instruments sample at $8 \mathrm{~Hz}$. Thus, the vertical resolution of data from the shipboard profiler was $<1 \mathrm{~cm}$. Data from the downward-looking acoustics package and the high-resolution profiler were integrated to provide sea-truthing for the acoustic and physical moorings.

2005 survey: In 2005, we conducted 4 shipboard surveys along the southwestern coast of Oahu. The overnight shipboard surveys coincided with spring (full moon April 23 to 25; new moon May 7 to 9; full moon May 22 to 24) and neap (first quarter May 15 to 17) tides. Each survey lasted for a period of $3 \mathrm{~d}_{\text {; }}$ sampling was undertaken during nighttime hours between 20:00 and 03:00 h. 
Transect pattern: Sampling during each 3 d survey was conducted continuously between 20:00 and 03:00 h local time. Transects formed a box around the mooring array. Acoustic sampling with the echosounders was conducted at a vessel speed of 5 knots. During each 3 d survey, vertical casts with the shipboard profiling package and a zooplankton net were carried out whenever the corners of the survey box were crossed and when the transects were near moorings B and D (6 stations total). The starting position along the survey grid was randomized each night, as was the order of the transects.

2006 survey: In 2006, we conducted 3 shipboard surveys along the northwestern coast of Oahu. The overnight shipboard surveys coincided with spring (full moon April 13 to 15; new moon April 26 to 28) and neap (third quarter May 12 to 14) tides. Each survey lasted for a period of $3 \mathrm{~d}$; sampling was undertaken during nighttime hours between 20:00 and 03:00 h. All surveys spanned both ebb and flood of each tidal cycle. Shipboard instrumentation was the same as 2005 sampling efforts.

Transect pattern: During each 3 d sampling effort in 2006, a $2 \mathrm{~km}$ wide box with a transect running down the center of each mooring array was sampled continuously from approximately 20:00 to 03:00 h local time at a speed of approximately 5 knots. Casts with the profiler and a vertical net tow were conducted near each of the moorings at 10,20,25, and $40 \mathrm{~m}$ each time they were passed. We decided randomly on the location of the first cast each night, as well as whether the first transect was run inshore or offshore and whether the right or left side flanking transect was sampled first.

Analysis of physical data. Data for winds and currents were low-pass filtered with a half-power period of $24 \mathrm{~h}$ for time-series plots shown. Temperature and current data were subdivided into $12 \mathrm{~d}$ sub windows with a $50 \%$ overlap, linearly detrended, and multiplied by a Hanning window to compute power spectra. Means and ranges reported for current speeds are from raw data.

Analysis of micronekton data. Echosounder moorings were calibrated using an indirect procedure incorporating reference targets, as in Benoit-Bird \& Au (2004). Data from the echosounder moorings were analyzed as in Benoit-Bird \& Au (2004), using echo-energy integration techniques to convert volume backscatter within the scattering layer into mean animal density by combining the target strength measurements made by Benoit-Bird \& Au (2001) with camera measurements of animal identity and size made during field surveys. The methods of Benoit-Bird \& Au (2006) were followed to determine animal identity, animal size, and numerical density of micronekton from the camera system.
The timing of layer appearance over a mooring was calculated as the first time that the average volume backscattering within the micronekton layer exceeded the equivalent of 0.5 micronekton $\mathrm{m}^{-3}$ and remained above this level for at least 3 measurements. The layer was considered to have moved out of the mooring location when the volume backscattering fell below this level for at least 3 consecutive measurements.

\section{RESULTS}

\section{Observations of physical processes}

Mesoscale and regional scale circulation patterns

In order to understand the local fluctuations in temperature and current velocity we observed at our moorings, it is necessary to understand the mesoscale and regional circulation patterns. The Hawaiian Islands are located within the subtropical gyre, a basin-wide clockwise gyre centered at $28^{\circ} \mathrm{N}, \sim 8^{\circ}$ north of Oahu. The island of Oahu is located in the Hawaiian Island chain between the islands of Molokai and Kauai (cf. Fig. 1). At the latitude of Oahu, winds are generally from the northeast and the predominant circulation is roughly from east to west. In the lee of the island (on the western side) counter-clockwise (cyclonic) eddies commonly form along the northwestern coast, and weaker, clockwise (anticyclonic) eddies are sometimes observed along the southwestern coast (Flament et al. 1996).

Winds

Northeasterly trade winds dominate over the Hawaiian Island chain. Due to orographic steering, trade winds encounter the west Oahu shoreline from the north and northwest and decrease from maximum velocities at the northern end of the study area toward the south. During surveys of the southwestern coast of Oahu in 2005, wind speeds were $5.80 \pm 2.72 \mathrm{~m} \mathrm{~s}^{-1}$ (mean $\pm \mathrm{SD}$ ). During surveys of the northwestern coast of Oahu in 2006, wind speeds were $6.10 \pm 3.17 \mathrm{~m} \mathrm{~s}^{-1}$ (Figs. 4 \& 5).

\section{Tides}

Tides along the west coast of Oahu are generally mixed, semi-diurnal, with 2 highs and 2 lows of unequal height each day. The surface tide propagates from north to south at the Hawaiian Islands, with little to no observed delay between 2005 and 2006 sites. 

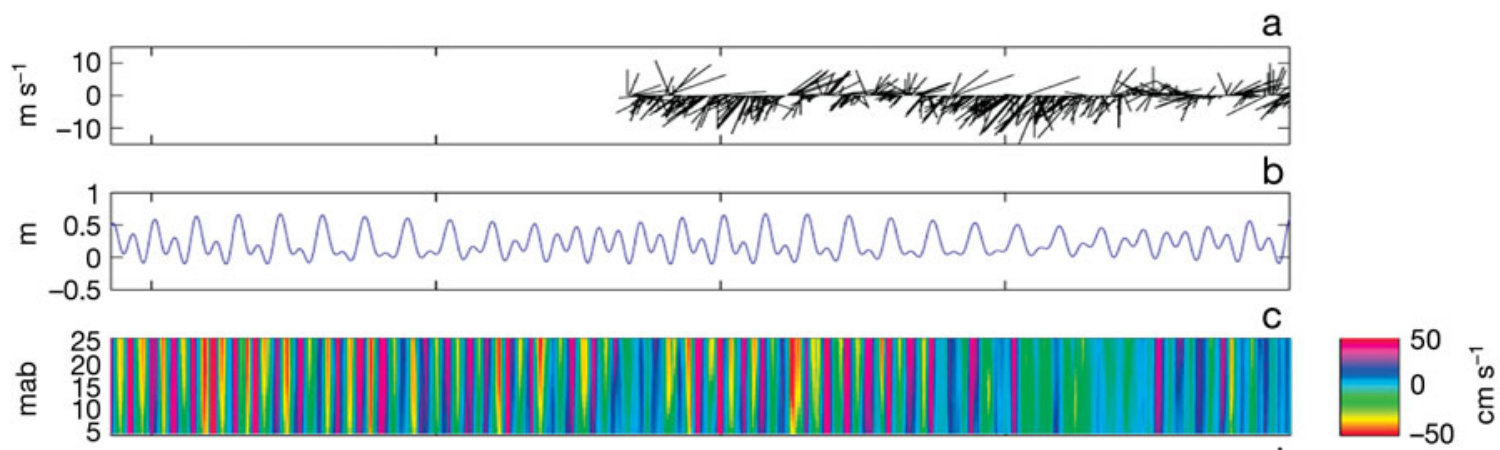

d
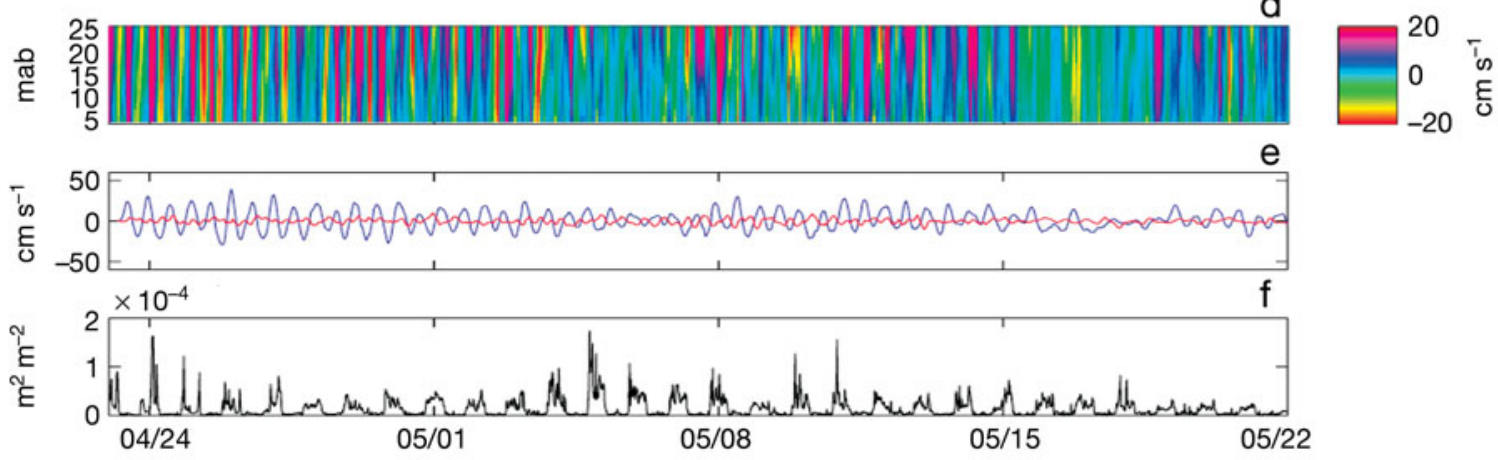

Fig. 4. Time series of data from 2005 study period (22 April to 22 May). (a) Hourly wind velocity ( $\mathrm{m} \mathrm{s}^{-1}$ ), (b) hourly tidal height (m), (c) hourly current velocity contours from ADCP oriented alongshore (positive- $y$ is northwest) (mab = m above bottom), (d) hourly current velocity contours from ADCP oriented cross-shore (positive- $y$ is northeast) (mab), (e) alongshore (along-isobath, blue) and across-shore (across-isobath, red) current magnitude from Nortek $\left(\mathrm{cm} \mathrm{s}^{-1}\right)$, (f) total water column backscatter $\left(\mathrm{m}^{2} \mathrm{~m}^{-2}\right)$. All data are from Mooring $\mathrm{C}(40 \mathrm{~m})$
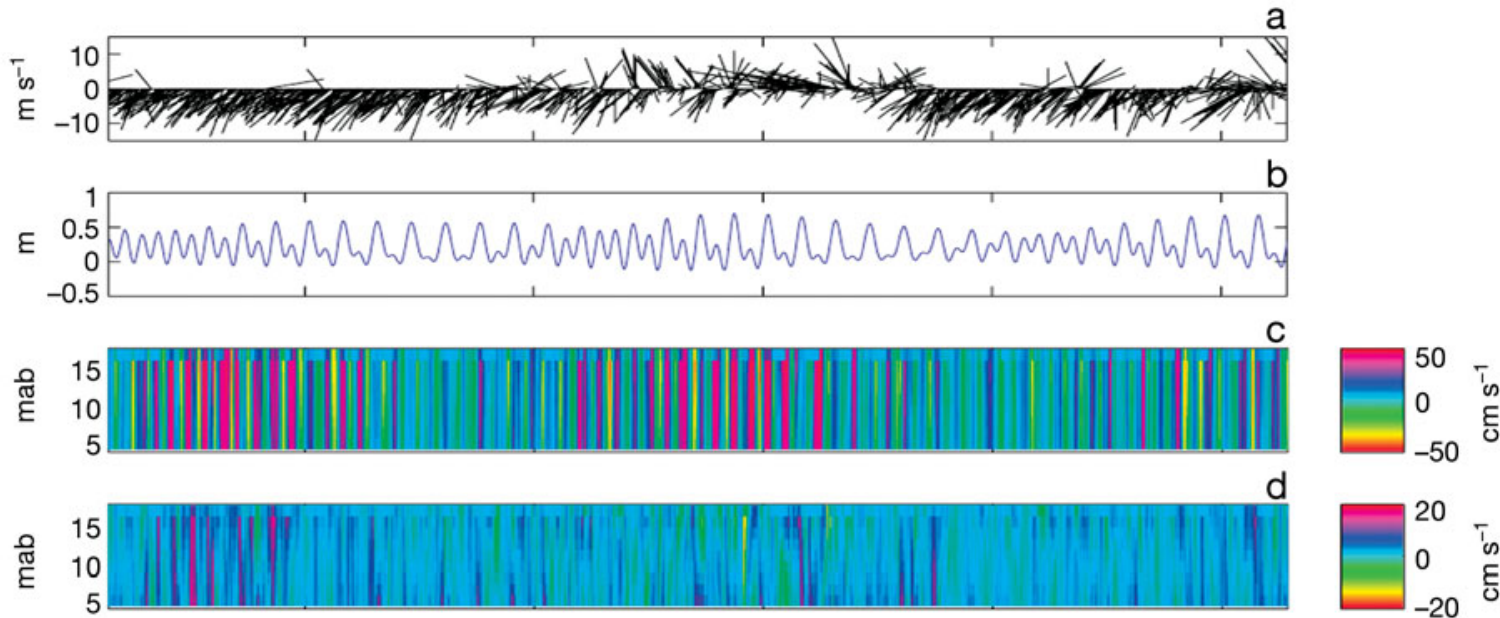

is $\begin{array}{r}50 \\ \text { Ec }\end{array}$

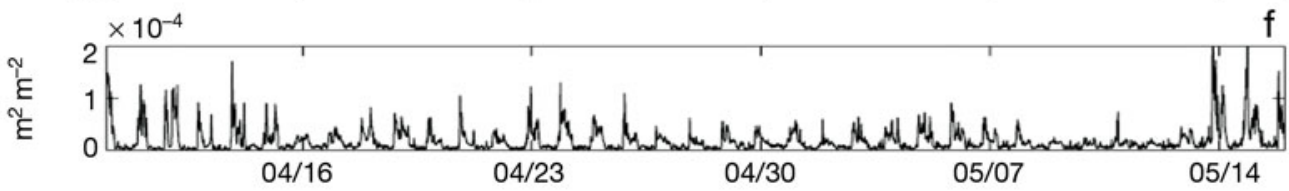

Fig. 5. Time series of data from 2006 study (10 April to 16 May). (a) Hourly wind velocity ( $\mathrm{m} \mathrm{s}^{-1}$ ), (b) hourly tidal height (m), (c) hourly current velocity contours from ADCP oriented alongshore (positive- $y$ is north, mab), (d) hourly current velocity contours from ADCP oriented cross-shore (positive-y is east, mab), (e) alongshore (along-isobath, blue) and across-shore (across-isobath, red) current magnitude from bottom-mounted Nortek $\left(\mathrm{Cm} \mathrm{s}^{-1}\right)$, (f) total water column backscatter $\left(\mathrm{m}^{2} \mathrm{~m}^{-2}\right)$. All data are from Mooring C $(25 \mathrm{~m})$ 


\section{General flow patterns}

General flow patterns along the western coast of Oahu are dominated by both surface and internal tidal forcing. All current measurements reported in this section are from bottom-mounted ADCP records for both study periods. Along the southwestern coast in 2005, alongshore (along-isobath) current velocities ranged from -57.21 to $65.73 \mathrm{~cm} \mathrm{~s}^{-1}$ with depth-averaged currents of $0.004 \pm 19.30 \mathrm{~cm} \mathrm{~s}^{-1}$ (where negative numbers represent currents moving in a southerly direction and positive numbers represent currents moving in a northerly direction). Cross-shore (cross-isobath) current velocities ranged from -33.23 to $29.10 \mathrm{~cm} \mathrm{~s}^{-1}$, with depth-averaged currents of $-3.62 \pm 6.80 \mathrm{~cm} \mathrm{~s}^{-1}$ (where negative numbers represent currents moving in an offshore direction, and positive numbers represent currents moving in an onshore direction). Daily depthaveraged currents were oriented parallel to shore (northwest to southeast) $80 \%$ of the time. Along the northwestern coast in 2006, alongshore (along-isobath) current velocities ranged from -39.03 to $46.84 \mathrm{~cm} \mathrm{~s}^{-1}$, with depth-averaged currents of $0.012 \pm 14.70 \mathrm{~cm} \mathrm{~s}^{-1}$. Cross-shore (cross-isobath) current velocities ranged from -30.58 to $45.58 \mathrm{~cm} \mathrm{~s}^{-1}$, with depth-averaged currents of $-2.76 \pm 5.90 \mathrm{~cm} \mathrm{~s}^{-1}$. Daily depth-averaged currents were oriented parallel to shore (north to south) $75 \%$ of the time. Cross-isobath currents were typically much stronger at the 2005 (southwestern) site than at the 2006 (northwestern) site, while alongisobath flows were comparable at both locations. The primary thermocline was situated between 40 and $60 \mathrm{~m}$ depth during the study, as determined from CTD profiler casts. This thermocline depth is typical of the nearshore Hawaiian Island waters.

\section{Onshore flows and cold-water intrusions}

Distinct pulses of cold water were observed in the near-bottom temperature records at the offshore moorings at $>25 \mathrm{~m}$ depth (Moorings B, C, D in 2005, Moorings C, D in 2006). These 'cold pulses' were associated with drops of up to $2^{\circ} \mathrm{C}$ in the local water temperature at the 2005 site (Fig. 6). Closer examination of the observed pulses revealed that they were stronger during or near spring tides.

At the 2005 site, cold pulses were associated with onshore currents occurring at the transition between ebb and flood tides. These onshore current velocities ranged from 0 to $10 \mathrm{~cm} \mathrm{~s}^{-1}$ recorded by Mooring $\mathrm{C}$ at $40 \mathrm{~m}$ depth during the spring tide (Fig. 6). Examination of the temperature power spectra showed distinct peaks at the semi-diurnal $(12 \mathrm{~h})$ and quarter-diurnal (6 h) periods (Fig. 6). Coldwater intrusions remained intact for roughly $4 \mathrm{~h}$ after each event.

At the 2006 site, we also observed near-bottom cold pulses at the Moorings $\mathrm{C}$ and $\mathrm{D}$. The cold pulses were again associated with onshore currents occurring on the ebb tide and the initiation of the transition between ebb and flood tides. These onshore velocities ranged from 0 to $8 \mathrm{~cm} \mathrm{~s}^{-1}$ at Mooring $\mathrm{C}$ during the spring tide
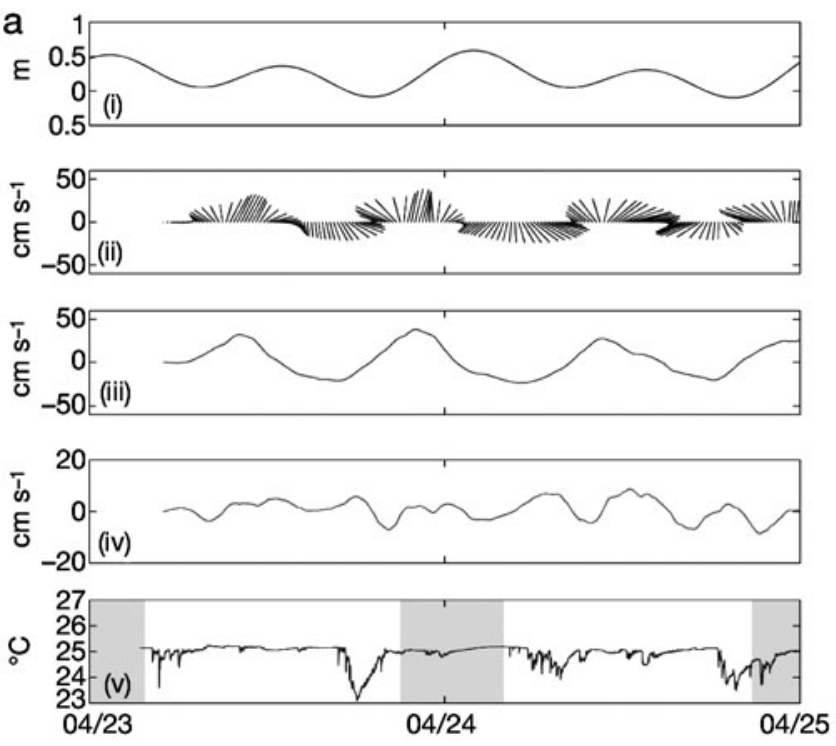

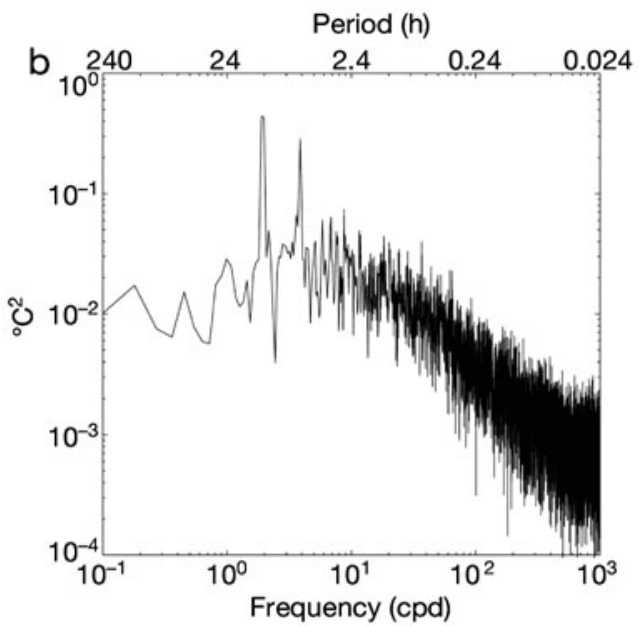

Fig. 6. Time series of 2005 data during spring tide (23 to 25 April). (a) (i) hourly tidal height (m), (ii) hourly $1 \mathrm{~m}$ above bottom (mab) current velocity vectors oriented alongshore (positive- $y$ is northwest) ( $\mathrm{cm} \mathrm{s}^{-1}$ ), (iii) along-shore (along-isobath) current magnitude $\left(\mathrm{cm} \mathrm{s}^{-1}\right)$, (iv) across-shore (across-isobath) current magnitude, positive values: onshore, negative values: offshore $\left(\mathrm{cm} \mathrm{s}^{-1}\right),(\mathrm{v})$ temperature at $1 \mathrm{mab}\left({ }^{\circ} \mathrm{C}\right)$. Grey shading in (v) indicates period when micronekton were inshore. (b) Power spectra of temperature time record $(\mathrm{cpd}=$ cycles per day). All data are from Mooring D $(40 \mathrm{~m})$. All current data are from bottommounted Nortek 
(Fig. 7). Power spectra of the near-bottom temperature record showed a significant peak at the quarterdiurnal $(6 \mathrm{~h})$ period as defined by the $95 \%$ confidence intervals (Fig. 7).

\section{Micronekton}

The shipboard camera system revealed that all micronekton identified in the nearshore soundscattering layer were myctophid fishes. Densities of micronekton measured with the camera system ranged from 2 to 194 fish $\mathrm{m}^{-3}$. Density estimates from the acoustic measures ranged from 1 to 246 fish $\mathrm{m}^{-3}$. Comparing the density estimates from individual camera casts to 10 min of acoustic data just before and after the cast showed that there was a nearly 1:1 relationship $\left(\mathrm{r}^{2}=0.96\right)$. This provides validation that the acoustic scattering is being correctly attributed to mesopelagic micronekton.

Migration timing was consistent between nights over individual moorings. In 2005, the layer appeared over Moorings B, C and D between 18:15 and 21:00 h local time with a mean at 20:00 h (Fig. 8). Sunset during this time changed nearly linearly from 18:54 to 19:09 h. The layer disappeared from this site between 02:15 and 04:30 h with a mean of 03:30 h. Sunrise during the sampling time varied from 06:09 $\mathrm{h}$ at the beginning of the study to 05:51 h at the end. Further inshore at the $26 \mathrm{~m}$ mooring, the patterns were similar, with the arrival of the layer between 15 and 30 min later than at the offshore moorings and the disappearance of the layer occurring between 15 and 30 min before the offshore moorings.

In 2006, the layer appeared over Mooring $\mathrm{E}$ between 18:00 and 21:07 h local time with a mean at 20:13 h. Sunset during this time changed nearly linearly from 18:50 to 19:05 h. The layer disappeared from this mooring between 02:58 and 04:18 $\mathrm{h}$ with a mean at 03:45 $\mathrm{h}$. Sunrise during the sampling time varied from 06:19 h at the beginning of the study to $05: 54 \mathrm{~h}$ at the end. The layer appeared an average of $17 \mathrm{~min}$ later at Mooring $\mathrm{C}$ and disappeared an average of 21 min earlier (Fig. 9).

For both years, the timing of migration appeared to be closely tied to the timing of sunrise and sunset. To test the possible role of light in cuing migration, a series of regressions were used to characterize the relationships between the changes in sunrise/sunset time (as provided by the US Naval Observatory) and layer appearance/disappearance represented in decimal time. There was no significant linear relationship between layer appearance and sunset time or layer disappearance and sunrise time at any mooring in either year (for all comparisons $r^{2}<0.1$, p $\gg 0.05$ ). However, layer appearance was strongly affected by moon phase at all moorings in both years. Simple linear regressions between percent lunar illumination (as provided by the US Naval Observatory) and layer
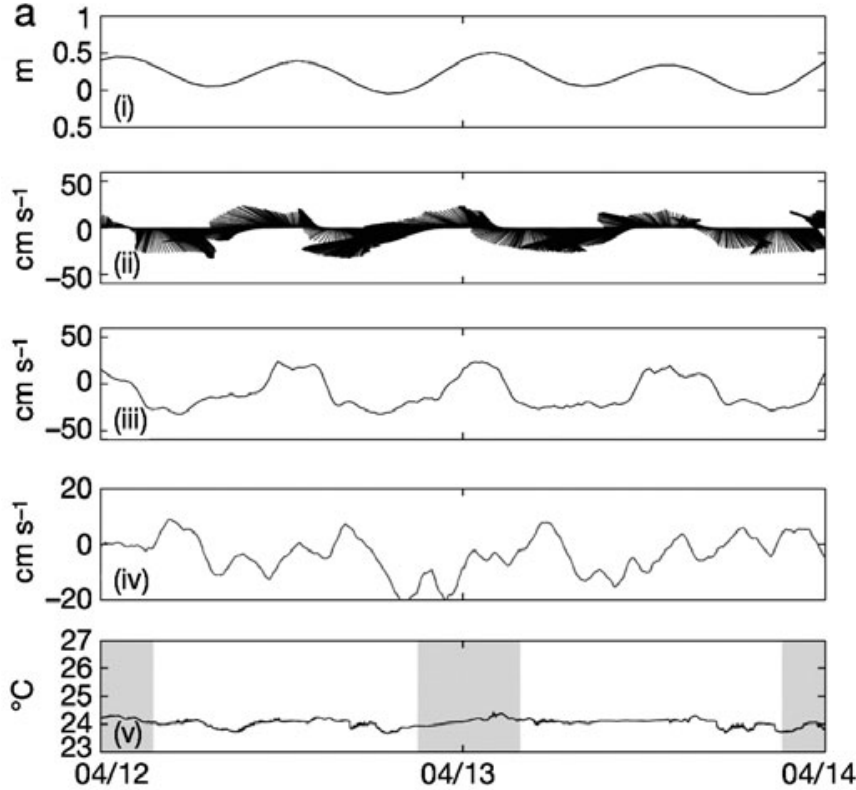

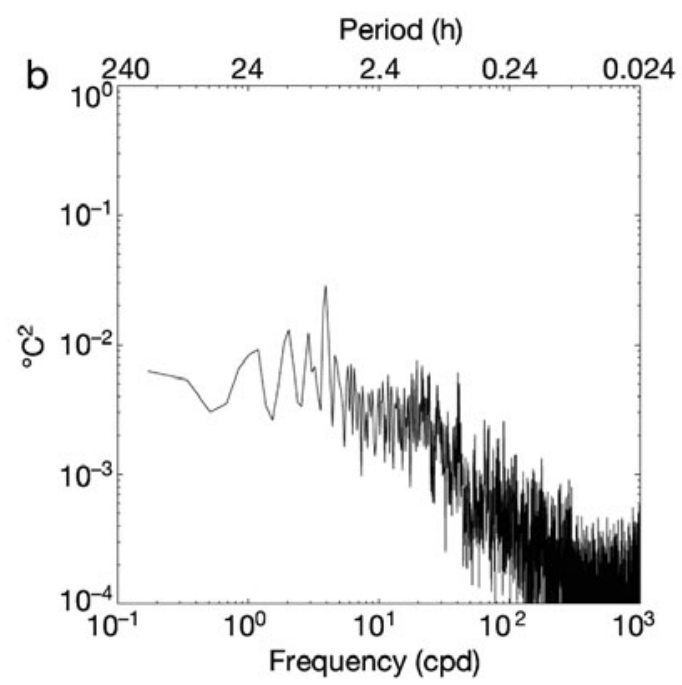

Fig. 7. Time series of 2006 data during spring tide (12 to 14 April). (a) (i) hourly tidal height (m), (ii) hourly 1 mab current velocity vectors oriented alongshore (positive- $y$ is north) $\left(\mathrm{cm} \mathrm{s}^{-1}\right)$, (iii) along-shore (along-isobath) current magnitude ( $\mathrm{cm} \mathrm{s}^{-1}$ ), (iv) acrossshore (across-isobath) current magnitude positive values: onshore, negative values: offshore $\left(\mathrm{cm} \mathrm{s}^{-1}\right)$, (v) temperature at 1 mab $\left({ }^{\circ} \mathrm{C}\right)$. Grey shading in (v) indicates period when micronekton were inshore. (b) Power spectra of temperature time record (cpd = cycles per day). All data are from Mooring C $(25 \mathrm{~m})$. All current data are from bottom-mounted Nortek 

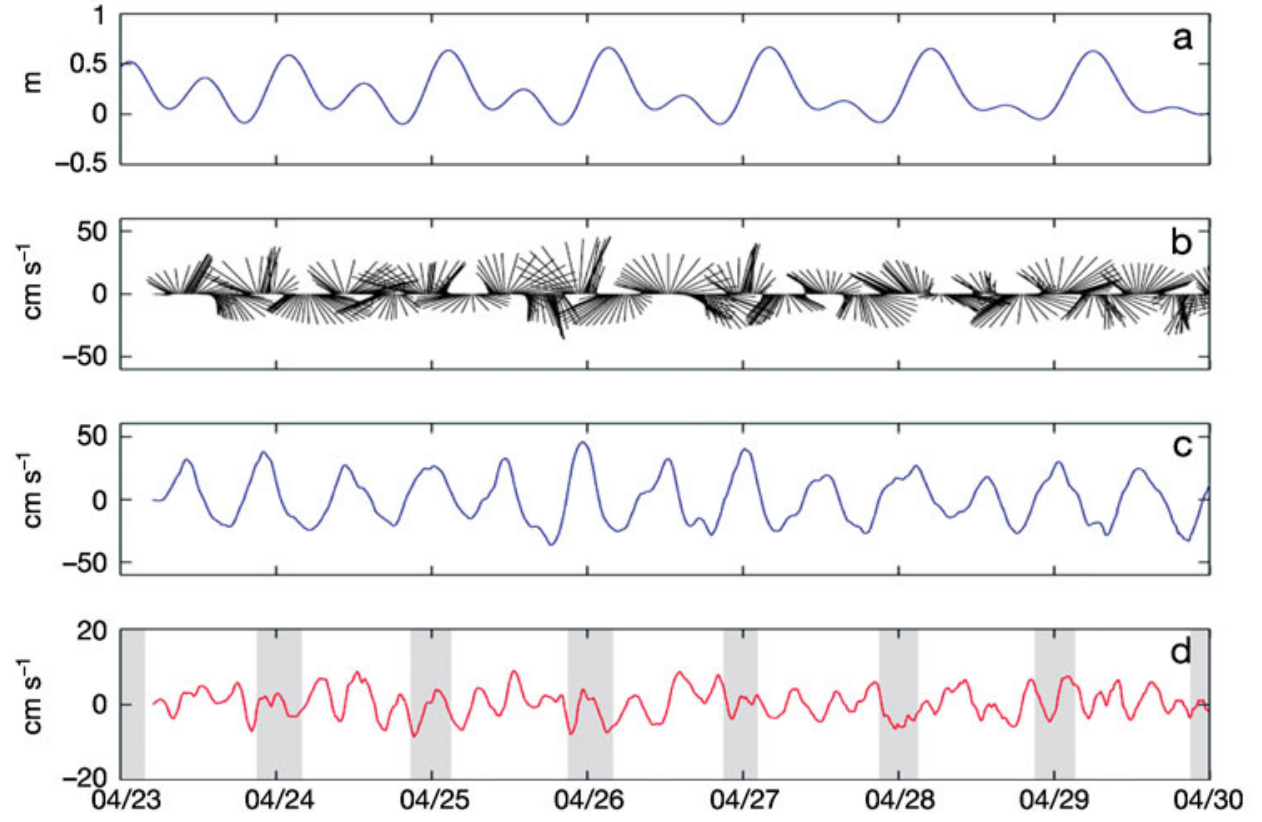

Fig. 8. Seven-day time series from mooring D in 2005 (40 m) showing (a) hourly tidal height (m), (b) hourly 1 mab current velocity vectors oriented alongshore (positive- $y$ is northwest) $\left(\mathrm{cm} \mathrm{s}^{-1}\right)$, (c) along-shore (along-isobath) current magnitude (cm s${ }^{-1}$ ), (d) across-shore (across-isobath) current magnitude positive values: onshore, negative values: offshore $\left(\mathrm{cm} \mathrm{s}^{-1}\right)$, shaded regions show period when micronekton are onshore (over array). Wind data were not available for this period. All current data are from bottom-mounted Nortek
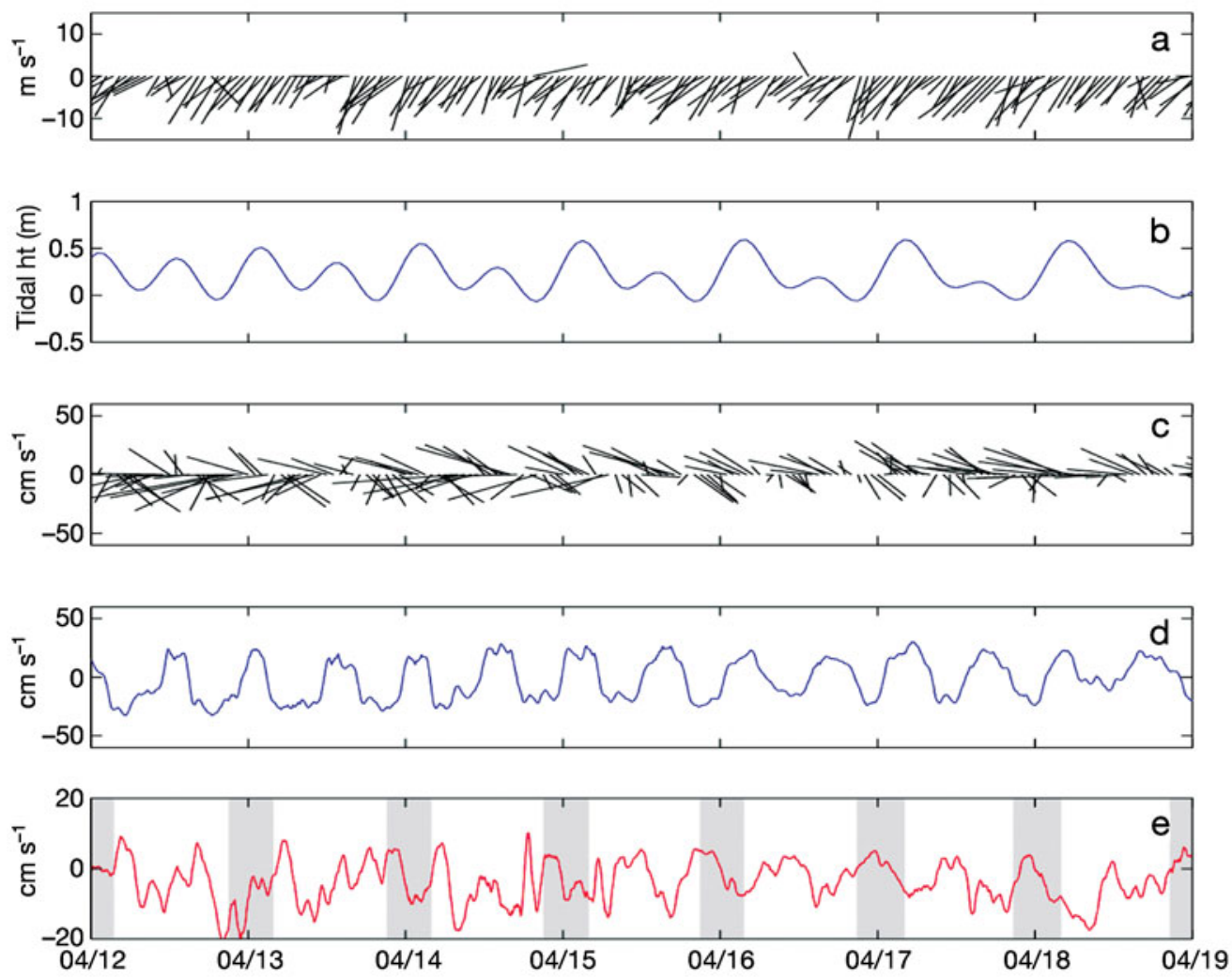

Fig. 9. Seven-day time series from mooring C 2006 (25 m) showing (a) hourly wind velocity, (b) hourly tidal height, (c) hourly 1 mab current velocity vectors oriented alongshore (positive- $y$ is north), (d) along-shore (along-isobath) current magnitude, (e) across-shore (across-isobath) current magnitude positive values: onshore, negative values: offshore, grey shaded regions show period when micronekton are onshore (over array). All current data are from bottom-mounted Nortek 
appearance time had goodness of fit values $>0.80$ for all moorings ( $p<0.05$ for all comparisons). The linear regressions for all moorings were similar, with a positive slope with values between 0.08 and 0.1 and $y$ intercepts between 0.7 and 0.9 (16:48 and 21:36 h, respectively).

\section{DISCUSSION}

\section{Onshore flows associated with cold-water intrusions}

We observed periodic rapid decreases in bottom water temperature of up to $2^{\circ} \mathrm{C}$ and $0.3^{\circ} \mathrm{C}$ at the 2005 (southwestern) and 2006 (northwestern) sites, respectively. Near-bottom temperature changes were most pronounced at the more offshore moorings during spring tides, and were closely correlated with the onset of onshore flow. Flow velocities during cold pulses were up to 8 and $10 \mathrm{~cm} \mathrm{~s}^{-1}$ at the 2005 and 2006 sites, respectively.

Cold pulses appeared to be associated with onshore movement of water caused by the internal tide generated at the Kaena Ridge, which is located northwest of the island of Oahu (Merrifield et al. 2001). The water column off the leeward coast of Oahu is typically characterized by a moderate $\left(\sim 2^{\circ} \mathrm{C}\right)$ primary thermocline near 40 to $60 \mathrm{~m}$ water depth (Hassett \& Boehlert 1999). Our observations of cold-water pulses on the leeward coast of Oahu are consistent with variation in the primary thermocline depth due to internal tides, which can lead to thermocline depth fluctuations of $40 \mathrm{~m}$ or more. The internal tide propagates away from Kaena Ridge along the western coast of Oahu in a southerly direction at $\sim 3 \mathrm{~m} \mathrm{~s}^{-1}$ (G. Carter pers. comm.). Differences in the timing of observed cold pulses between the 2005 (southwestern) and 2006 (northwestern) sites (in relation to the surface tide) also suggest a southerly propagation of the internal tide generated at the Kaena Ridge.

\section{Micronekton migration}

Micronekton migration patterns at both the 2005 and 2006 sites were similar and matched well with previous studies off both Oahu and other areas in the Hawaiian Islands (Benoit-Bird et al. 2001, Benoit-Bird $\&$ Au 2004, 2006). The timing of the layer's arrival and subsequent departure was remarkably consistent, with layer rise times having a maximum $95 \%$ confidence interval of just over $17 \mathrm{~min}$, and layer set times having a $95 \%$ confidence interval of less than 10 min at every mooring in each year. There was no significant correlation between the tidal height at sunset and the timing of layer rise ( $p<0.05$ for each comparison, $1-\beta=0.89$ ) or the tidal height at sunrise and layer set time $(p<0.05$ for each comparison, $1-\beta=0.94)$. Based on the timing of the micronekton scattering layer over individual moorings, the layer's migration rate near the inshore edge of its nighttime distribution averaged $0.5 \mathrm{~m} \mathrm{~s}^{-1}$ inshore after sunset and offshore before sunrise.

The layer's inshore migration appeared to be related to the time of sunset and its offshore movement to sunrise. However, there was no significant calculated relationship between changes in the timing of these solar events and the measurements of migration timing. While sunlight may play a role in cuing migration, at least with the relatively small changes in sunrise and sunset timing observed during the study periods (representing about $20 \%$ of the yearly variation), its effects appear to be mediated by other cues or pressures. Changes in the onset of inshore horizontal migration were related to lunar phase or a covariate of lunar phase, perhaps moonlight, with an observed effect of approximately $2 \mathrm{~h}$ over a full lunar cycle. Offshore movement did not show this effect. These results suggest potential proximate mechanisms for the initiation of horizontal migration.

While the signal of micronekton movement onto the shelf occurs very predictably each day: onshore migration brings animals nearshore at 20:00 to 20:13 h and offshore migration commences at roughly 03:30 to 03:45 h (mean migration times from 2005 and 2006, respectively), observed cold pulses and inshore movements of water are tied to the phase of the internal tide, which progresses by roughly 42.5 min each day. These periodic inshore movements of water are not associated with any specific time of day (Figs. 8 \& 9). Given these offsets in timing, nightly micronekton movement onto the shelf does not appear to be tied to these pulses of cold water. This is an indication that micronekton are not passively advected into the study region, rather they are actively migrating into coastal waters.

As previously mentioned, cold pulses at both sites were correlated with onshore currents. Maximum onshore current velocities during these events were $8 \mathrm{~cm} \mathrm{~s}^{-1}$ (25 m mooring) and $10 \mathrm{~cm} \mathrm{~s}^{-1}$ (40 m moorings), respectively, at the 2006 and 2005 sites during the spring tide, while the average onshore migration speed for the micronekton layer was $50 \mathrm{~cm} \mathrm{~s}^{-1}$. Thus, even at peak onshore velocity (generated by periodic cold pulses), the micronekton layer was moving onshore 5 to 6 times faster than the physical flow field. When cold pulses do coincide with onshore migration, it is possible that the animals use this flow to reduce their energy expenditures; however, these events are not being used as primary mechanisms for the inshore transport of the micronekton layer. A correlation analysis between onshore flow velocity and acoustic 
backscatter resulted in no significant relationship between nightly micronekton movements and onshore flow. This further supports our conclusion that micronekton are not passively advected into the study region, rather they are actively migrating into coastal waters.

This behaviorally driven movement is different from the behavioral movements by micronekton observed near a seamount in the Northwest Hawaiian Islands, which nearly balanced horizontal movement by advection and thus facilitated retention near the seamount (Wilson \& Boehlert 2004). It is likely that the horizontal migration we observed also provides a mechanism for retention in the narrow zone of favorable habitat surrounding the Hawaiian Islands.

Acknowledgements. This work was funded by the Office of Naval Research awards \# N00014-05-1-0035 (M.A.M.), \#N00014-051-0034 (K.J.B-B.). We thank the Ko'Olina Marina Harbormaster, M. Daily, B. McLaughlin, D. Merrit, C. Ostrander, D. Pence, J. Reich (Captain of the Fishing Vessel 'Alyce C'), J. Smith, I. Z. Steward, G. Steward, C. Stoebenau, O. Vetter, and C. Waluk for their assistance in the field and/or initial data processing and $\mathrm{W}$. Au, M. Baumgartner, T. Cowles, B. Mate, C. Miller, C. Wingard, and the Pacific Islands Fisheries Science Center for loaning some equipment for this study. We thank 3 anonymous reviewers for their helpful comments and suggestions. D. V. Holliday and C. Greenlaw assisted with equipment repair during field operations. C. Miller and C. Smith provided laboratory space. W. Au, M. Benfield, and D. V. Holliday provided important discussions during the early phases of this work.

\section{LITERATURE CITED}

Benoit-Bird KJ, Au WWL (2001) Target strength measurements of animals from the Hawaiian mesopelagic boundary community. J Acoust Soc Am 110:812-819

Benoit-Bird KJ, Au WWL (2004) Diel migration dynamics of an island-associated sound-scattering layer. Deep-Sea Res 51:707-719

Benoit-Bird KJ, Au WWL (2006) Extreme diel horizontal migrations by a tropical nearshore resident micronekton community. Mar Ecol Prog Ser 319:1-14

Benoit-Bird KJ, Au WWL, Brainard RE, Lammers MO (2001) Diel horizontal migration of the Hawaiian mesopelagic

Editorial responsibility: Matthias Seaman, Oldendorf/Luhe, Germany boundary community observed acoustically. Mar Ecol Prog Ser 217:1-14

Blaxter JHS (1974) The role of light in the vertical migration of fish - a review. In: Evans GC, Bainbridge R, Rackham O (eds) Light as an ecological factor II: The 16th symposium of the British Ecological Society. Blackwell Scientific Publications, Oxford

Clarke GW (1970) Light conditions in the sea in relation to the diurnal vertical migrations of animals. In: Farquar GB (ed) Proceedings of an international symposium on biological sound scattering in the ocean. Department of the Navy, Washington, DC, p 41-50

Enright JT (1977) Diurnal vertical migration: adaptive significance and timing. Limnol Oceanogr 22:856-886

Flament P, Kennan S, Lumpkin R, Sawyer M, Stroup ED (1996) Ocean atlas of Hawaii. University of Hawaiii, Honolulu, HI. Available at: www.satlab.hawaii.edu/atlas/

> George DG (1983) Interrelations between the vertical migration of Daphnia and chlorophyll a in two large limnetic enclosures. J Plankton Res 5:457-475

Hassett RP, Boehlert GW (1999) Spatial and temporal distributions of copepods to leeward and windward of Oahu, Hawaiian Archipelago. Mar Biol 134:571-584

Lampert W (1989) The adaptive significance of diel vertical migration of zooplankton. Funct Ecol 3:21-27

Longhurst AR (1976) Vertical migration. In: Cushing DH, Walsh JJ (eds) The ecology of the seas. W.B. Saunders Company, Philadelphia, p 116-137

> Merrifield MA, Holloway PE, Johnston TMS (2001) The generation of internal tides at the Hawaiian Ridge. Geophys Res Lett 28:559-562

Reid SB (1994) Spatial structure of the mesopelagic fish community in the Hawaiian boundary region. $\mathrm{PhD}$ thesis, University of Hawaii, Honolulu

Reid SB, Hirota J, Young RE, Hallacher LE (1991) Mesopelagic-boundary community in Hawaii: micronekton at the interface between neritic and oceanic ecosystems. Mar Biol 109:427-440

Ringelberg J (1995) Changes in light intensity and diel vertical migration: a comparison of marine and freshwater environments. J Mar Biol Assoc UK 75:15-25

Roe HSJ (1974) Observations on the diurnal vertical migrations of an oceanic animal community. Mar Biol 28:99-113

Valle-Levinson A, Trasvina Castro A, Gutierrez de Velasco G, Gonzalez Armas R (2004) Diurnal vertical motions over a seamount of the southern Gulf of California. J Mar Syst 50:61-77

> Wilson CD, Boehlert GW (2004) Interaction of ocean currents and resident micronekton at a seamount in the central North Pacific. J Mar Syst 50:39-60

Submitted: April 20, 2007; Accepted: March 25, 2008

Proofs received from author(s): July 9, 2008 